\title{
Associativismo no Setor Saúde Brasileiro e Organizações de Interesse do Empresariado Médico
}

MARIA ELIANA LABRA*

\section{Política, interesses e concertação: algumas premissas teóricas}

O funcionamento do sistema político democrático no Brasil contemporâneo vem colocando em pauta a necessidade de entender as relações Estado-sociedade sob um novo prisma. Em geral, as interpretações sobre essa dinâmica têm se centrado, por um lado, na potencial supremacia do Estado na ordem corporativa e, por outro, na autonomia da ordem associativa. À luz dessas visões, as transformações aparecem como iniciativas e concessões do Estado ou, inversamente, como conquistas sociais. Tal como assinalam Diniz e Boschi, ${ }^{1}$ a ênfase ora na capacidade primordial do Estado de plasmar

* Mestre em Administração Pública (EBAP/FGV), Doutoranda em Ciência Política (Iuperj), pesquisadora assistente e professora do Departamento de Planejamento e Administração da Escola Nacional de Saúde Pública/Fiocruz. Agradeço à prof ${ }^{2}$ Maria Lúcia Werneck Vianna pelas valiosas observações que fez ao texto original e que me permitiram dar maior coerência à exposição e conclusões. Obviamente, as deficiências persistentes são da minha inteira responsabilidade.

1 E. Diniz e R. R. Boschi, "Corporativismo na Construção do Espaço Público", in R. R. Boschi, org., Corporativismo e Desigualdade: A Construção do Espaço Público, Rio de Janeiro, Rio Fundo/Iuperj, 1991. 
a sociedade e os interesses, ora na primazia da sociedade na estruturação do poder político também está presente no pensamento social brasileiro, introduzindo uma tensão que emerge quando se trata de atribuir um papel modernizador ao pólo estatal ou ao pólo associativo. Por extensão, identifica-se corporativismo, atraso e autoritarismo com o primeiro modelo, e democracia e modernidade com o segundo.

A experiência de muitas democracias contemporâneas, no entanto, revela que o sistema político é mais complexo que o sugerido por essas polaridades, também motivo de controvérsia entre os paradigmas pluralista e marxista de explicação da ordem social. ${ }^{2}$ A esse respeito, os modernos enfoques sobre o corporativismo - o neocorporativismo - vêm apontando para a insuficiência das teorias baseadas na centralidade atribuída à comunidade, ao mercado econômico/político ou ao Estado/burocracia, posto que, na realidade, o que existe é uma mistura dessas instituições e de seus respectivos princípios de funcionamento - a solidariedade espontânea, a competição dispersa e o controle hierárquico. ${ }^{3}$ Para além dessas distinções, observa-se hoje em dia a configuração de uma outra base institucional da ordem social que transcende e amalgama as anteriores e tem capacidade para tornar mais previsível e ajustável a conduta dos atores sociais. Essa quarta dimensão é constituída pela associação, sendo seu princípio de interação a concertação organizacional. ${ }^{4}$

A existência de sistemas políticos/econômicos de acomodação de interesses negociados e de políticas de concertação torna imprescindível, portanto, a consideração das associações de interesse enquanto atores que desem-

2 R. R. Boschi, “A Teoria Marxista e o Desafio Neocorporativo", Presença, no 15, 1990, pp. 36-54; E. Diniz e R. R. Boschi, "Corporativismo na Construção...", op. cit.; M. E. Labra, "Política de Interesses na Perspectiva Neocorporativista: Subsídios para o Estudo do Setor Saúde", in E. Gallo et alli, orgs., Planejamento Criativo: Novos Desafios em Políticas de Saúde, Rio de Janeiro, Relume-Dumará, 1992, pp. 115-37.

3 W. Streeck e P. C. Schmitter, "Community, Market, State - and Associations?", in W. Streeck e P. C. Schmitter, eds., Private Interest Government. Beyond Market and the State, Londres, Sage, 1985, pp. 1-29; P. C. Schmitter, "Neo-Corporatism and the State", in W. Grant, ed., The Political Economy of Corporatism, Nova Iorque, St. Martin's Press, 1985, pp. 32-62; M. E. Labra, "Política de Interesses...", op. cit.

4 O termo concertação refere-se a uma prática política ou mecanismo de mediação pelo qual o Estado comparte institucionalmente a responsabilidade pelo desenho e execução de políticas sócio-econômicas com atores sociais organizados. Ver, a respeito, M. dos Santos et alli, Concertación Político-Social y Democratización, Buenos Aires, Clacso, 1987; W. Streeck e P. C. Schmitter, "Community, Market, State...”, op. cit.; A. Cawson, Corporatism and Political Theory, Oxford, Blackwell, 1986. 
penham papel crucial nos processos de formulação de políticas públicas. Trata-se de um novo modelo, cuja especificidade está relacionada a dois atributos básicos: o escambo político entre os setores público e privado ${ }^{5}$ e a organicidade e concentração da estrutura de representação. Mais explicitamente, refere-se a um formato de intermediação fundado no ordenamento hierárquico de grupos ou categorias funcionais, baseado na afiliação compulsória e na representação monopólica, cuja ação se dirige à burocracia estatal. Nesse sentido, as prioridades de política pública resultam de processos negociados sob a supervisão do Estado e dentro de uma lógica de acordo ou concertação, o que reduz o conflito de interesses. Idealmente, nessa dinâmica, a democracia é parte e produto de um permanente ajuste de interesses possibilitado pela configuração de amplas coalizões, envolvendo, nos casos mais conspícuos, representantes do capital, do trabalho e do Estado, de forma a assegurar, razoavelmente, políticas adequadas às partes em questão, mas que afetam a toda a sociedade.

Essa configuração, que mostra extrema variedade segundo o país a que se refira, tem respondido por boa parte do alto grau de governabilidade das modernas democracias, o que não significa uma simplificação dos processos de decisão pública ${ }^{6}$ Muito pelo contrário, o que se constata é a existência de uma verdadeira rede de políticas, cujo processo de formulação inclui um grande número de atores públicos e privados de diferentes níveis e áreás funcionais do governo e da sociedade. Tais redes surgem em resposta a novas características do processo público em sociedades complexas que estão a reafirmar o fenômeno neocorporativo. Com efeito, observa-se que, cada vez mais as sociedades se baseiam em coletividades organizadas; o Estado tende à descentralização ou fragmentação; o processo decisório estatal adquire escopo crescente e setorizado; as fronteiras das esferas pública e privada tornam-se opacas, difusas. ${ }^{7}$

5 O conceito de escambo político pode ser definido como uma relação entre o Estado e grupos de interesse por meio da qual o primeiro cede parte de sua autoridade de decisão a esses grupos em troca da garantia destes quanto à adesão de seus membros às decisões alcançadas em conjunto. Ver M. J. Bull, "The Corporatist Ideal-Type and Political Exchange", Political Studies, vol. $\mathrm{XL}, \mathrm{n}^{\circ} 2,1992$, pp. 255-72.

6 Ver P. C. Schmitter, "Interest Intermediation and Regime Governability in Contemporary Western Europe and North America", in S. Berger, ed,, Organizing Interests in Western Europe: Pluralism, Corporatism and the Transformation of Politics, Cambridge, Cambridge University Press, 1981, pp. 285-327.

7 G. Jordan e K. Schubert, "A Preliminary Ordering of Policy Network Labels", European Journal of Political Research, $\mathrm{n}^{\circ}$ 21, 1992, pp. 1-17. 
Esses desenvolvimentos, por certo, encorajam tendências nem sempre positivas, tais como: sobrecarga da agenda pública; fragmentação do aparato estatal em um mosaico de interesses departamentais; o policy-making tende a realizar-se entre frações do Estado e grupos de interesse clientelistas. Contudo, boa parte dessas tendências, normais em qualquer democracia. tem sido contornada justamente por meio da formalização de um espaço público onde têm lugar a negociação e o consenso entre organizações de interesse reconhecidas legalmente pelo Estado, e cujos representantes legítimos detêm o controle sobre a adesão dos membros da associação ao pacto.

Mas os defensores do pluralismo, por exemplo, ao enfatizarem os aspectos negativos da intermediação corporativa de interesses. têm tentado conceder ao seu modelo um valor prescritivo universal (a partir da idealização da experiência norte-americana) ao preconizarem um Estado mínimo, articulado em torno de um sistema bipartidário, comportando fortes grupos de pressão e uma multiplicidade de sindicatos autônomos, todos altamente competitivos entre si tanto no mercado econômico quanto no político. Contrariamente, a realidade mostra que nas democracias contemporâneas há uma convivência de formatos corporativos e pluralistas de policy-making e não uma exclusão dessas formas de intermediação.

Tais experiências, por outro lado, em boa medida, refutam alguns postulados do enfoque marxista, no sentido de que não necessariamente as clivagens e os interesses que perpassam a sociedade capitalista se baseiam somente nas relações de produção; não é a pura dinâmica da luta de classes o que anima a transformação dos interesses das pessoas e a organização destas em grupos específicos; nem sempre a fonte de poder reside na instância econômica (a própria organização forte, centralizada, é um recurso de poder crucial na sociedade atual); nem sempre a luta pelo poder se traduz em um jogo de soma zero em que um grupo ganha a expensas do outro. Justamente, a idéia de concertação entre atores antagônicos traduz a disposição das partes de negociar os custos e os benefícios que qualquer pacto implica, em prol de algum interesse maior, como, por exemplo, a paz social (caso típico da Europa no pós-Segunda Guerra) ou a manutenção de direitos sociais em face da dita crise do Welfare State dos anos 70, que também afetou o setor saúde.

Como, em conseqüência, nem a competição de grupos e a pressão lobbista, nem a dominação de classe por intermédio do Estado capitalista explicam, por si só, os resultados das políticas públicas nas democracias capitalistas contemporâneas, o enfoque da dimensão associativa torna-se indispensável para compreender a dinâmica dos sistemas políticos. A esse 
respeito, mais uma vez se coloca a questão da especificidade dos casos nacionais em relação, por exemplo, a fatores tais como: o peso relativo dos partidos políticos e do Parlamento, os graus de centralização das estruturas de representação de interesses e de permeabilidade das agências burocráticas às pressões externas, bem como o padrão de inclusão/exclusão de diferentes segmentos sociais nos acordos corporativos. Outras variações possíveis referem-se, também, à origem societal ou estatal do formato associativo, ao tipo tri ou bipartite da concertação e à instância onde os arranjos de intermediação de interesses têm lugar, que pode ser nacional, setorial ou local, o que leva à distinção entre macro, meso e micro-corporativismo. ${ }^{8}$

Assim, as teorias neocorporativas tendem hoje a focalizar o plano meso - posição intermediária entre o nível macro da economia e micro da empresa - e não mais o sistema econômico-social como um todo, enquanto unidade central de análise das mudanças na política pública, na estruturação do mercado e na tecnologia. Seria o setor o locus onde as trocas entre agentes e produtores se constróem socialmente e onde a política pública se concretiza em ações administrativas. Schmitter considera que o setor, embora seja apenas uma ilusão criada pelos dados que se quer investigar ou pelas estatísticas disponíveis, é uma arena decisória e também uma variável explicativa da estrutura social. O setor seria uma configuração determinada pelas percepções e decisões dos atores, consolidada desde a base pelas unidades singulares e de cima para baixo pelas agências estatais que, além de incentivarem o desenvolvimento dessas, favorecem o acesso privilegiado aos beneficiários da política, estabelecendo com estes relações específicas de clientela. $\mathrm{O}$ autor acrescenta que é exatamente no setor que se pode construir uma rede de relações sociais, incluindo governos privados, quer dizer, hierarquias privadas reguladas pela autoridade pública, cujo comportamento é pautado pela concertação coletiva entre os atores sociais. ${ }^{9}$

A luz das breves considerações teóricas acima, nas páginas seguintes desenvolvo uma exposição que tem o propósito de introduzir elementos analíticos e empíricos para uma avaliação das condições de viabilidade de um pacto social entre os principais atores organizados do setor saúde, dado o alto grau de complexidade e maturidade alcançado pelo associativismo

8 A. Cawson, ed., Organized Interests and the State: Studies in Meso-Corporatism, Londres, Sage, 1985; A. Cawson, Corporatism and Political.... op. cit.; M. E. Labra, "Política de Interesses..." op. cit.

9 P. C. Schmitter. "I Settori nel Capitalismo Moderno: Modi di Regolazione e Variazoni nel Rendimento"., Stato e Mercato, n² 26, 1989, pp. 173-208. 
setorial. Na seqüência, examino brevemente aspectos muito gerais das relações Estado-sociedade no Brasil. Em seguida, apresento uma exposição sucinta dos principais fatos político-institucionais ocorridos no setor saúde desde os anos 20. Acrescento um exame das formas pelas quais os interesses setoriais (profissões, empresariado industrial e assistencial) têm organizado sua representação, bem como reflexões a respeito das peculiaridades que, no meu entender, o caso brasileiro apresenta. Finalmente, dou destaque à descrição das organizações de interesse do empresariado médico-assistencial. A exposição é ilustrada por um quadro sinóptico que permite apreciar a evolução cronológica da configuração das organizações setoriais de representação nacional vis-à-vis momentos marcantes das políticas de saúde, por um lado, e, por outro, a institucionalização de arenas oficiais de participação colegiada.

\section{Padrões de organização e intermediação de interesses no Brasil ${ }^{e}$}

Uma característica central e própria do modelo associativo brasileiro, que a recente democratização trouxe à tona com clareza, refere-se ao fato de se tratar de um sistema híbrido ou dual no que tange às origens das corporações sindicais, empresariais e profissionais. ${ }^{10}$

Historicamente, até a Revolução de 1930, predominou no País uma tendência liberal pluralista quanto à organização e representação de interesses e uma forma de articulação público/privado pautada pelo patrimonialismo, quer dizer, por uma visão do público como mera extensão do privado. Com a Constituição de 1937 (de inspiração fascista), institucionaliza-se no País o corporativismo de Estado, que passa a incorporar à sua esfera os atores políticos e sociais mais relevantes. Sob o primado estatal, que viria a presidir a instauração da ordem industrial capitalista, a montagem da estrutura corporativa esteve destinada a moldar e controlar as relações Estado-sociedade civil, sendo cancelada, ao mesmo tempo, a representação parlamen-

10 A sumária caracterização que se segue está baseada fundamentalmente nas seguintes contribuições: R. R. Boschi, A Arte da Associação. Politica de Base e Democracia no Brasil, São Paulo, Vértice/Iuperj, 1987; A. Camargo e E. Diniz, orgs., Continuidade e Mudança no Brasil da Nova República, São Paulo, Vértice/Iuperj, 1989; E. Diniz, R. R. Boschi e R. Lessa, Modernização e Consolidação Democrática no Brasil: Dilemas da Nova República, São Paulo, Vértice/Iuperj, 1989; L. W. Vianna, A Transição. Da Constituinte à Sucessão Presidencial, Rio de Janeiro, Revan, 1989. 
tar e a atividade político-partidária, o que conduziu, na prática, à desarticulação entre os partidos e os interesses organizados.

Em suma, é pela via do Estado que esses setores adquirem identidade coletiva e se configuram como atores políticos estratégicos para o desenvolvimento industrial. Ao mesmo tempo, é inaugurado um sistema decisório fechado e excludente que sinaliza para uma nova forma de articulação entre as esferas pública e privada. Sem que se perdessem totalmente as características patrimonialistas, por um lado se estreitaram os vínculos entre grupos capitalistas com interesses específicos e segmentos funcionais da burocracia estatal e, por outro, essas arenas ganharam progressiva autonomia quanto ao poder de definir políticas setoriais e de se subtrair aos controles fiscal, político e social.

Quanto à dimensão associativa, em meados dos anos 40 , podem ser observadas duas tendências. Os interesses empresariais passam a se organizar em associações privadas, funcionando à margem da estrutura corporativa oficial, ao mesmo tempo em que se recompõem no interior do aparelho estatal os espaços para a representação e intermediação desses interesses, por meio de conselhos ou colegiados que fornecem novas bases de legitimidade às alianças entre as elites econômicas e tecno-burocráticas. Quanto ao operariado, este ficou prisioneiro de uma estrutura corporativa vertical e hierarquizada tutelada pelo Ministério do Trabalho, tendo em vista que os sindicatos foram alijados da participação em quaisquer arranjos tripartites de negociação ou de parceria social.

De fato, contrariamente à experiência européia de corporativismo societal e de concertação abrangente, na experiência corporativa brasileira o Estado não chegou a promover acordos entre as classes fundamentais. Em vez disso, propiciou: a segmentação dos interesses do capital; um intercâmbio político baseado em perspectivas particularistas de curto prazo; um padrão bipartite de negociação entre o empresariado e a alta burocracia pública; uma participação limitada desse a algumas fases do processo decisório (consulta e implementação), que todavia não impediu a privatização da coisa pública; e o controle da organização dos trabalhadores urbanos. No plano mais geral, o corporativismo estatal consagrou um sistema político antidemocrático e socialmente excludente e transformou a burocracia pública em arena privilegiada de decisão e mediação entre o Estado e a sociedade.

Uma questão que é objeto de controvérsia tem a ver com a capacidade de sobrevivência e adaptação do corporativismo brasileiro às transformações de toda ordem operadas no País nos anos 50 e, particularmente, dos anos 70 em diante. Polêmicas à parte, os fatos revelam que, embora a estrutura 
corporativa prevaleça, ela se tornou substantivamente mais flexível e proclive à convivência com formas de organização e representação de interesses de origem societal.

Como resultado inexorável e não-intencional dessa complexificação, emergiram e proliferaram associações vinculadas aos setores médios urbanos (profissionais liberais, funcionários do setor de serviços e de empresas estatais etc.), bem como movimentos sociais, emprestando uma feição pluralista à dimensão associativa da ordem social. Não obstante esse fenômeno de modernização da constelação de interesses organizados, deve ser salientado que foram preservados traços que limitam e tensionam a consolidação da democracia no Brasil, tais como a abissal desigualdade estrutural entre empresários e trabalhadores, a fragilidade endêmica dos partidos políticos e uma herança cultural autoritária que obstaculiza o reconhecimento do outro como interlocutor legítimo.

Diniz e Boschi afirmam que, no caso brasileiro, considerando as possíveis formas de articulação Estado/sociedade, o mais provável é que se tenha um sistema híbrido, marcado pela coexistência de diversos padrões, com a persistência do corporativismo tradicional, embora bastante atenuado em sua rigidez original, o desenvolvimento dos núcleos pluralistas, sobretudo nos grandes centros urbanos e o surgimento do neocorporativismo como uma alternativa de participação dos grupos privados em certas arenas de decisões, sobretudo em certas áreas de política econômica e ambiental. ${ }^{11}$

Podemos encerrar esta seção assinalando que um dos objetivos centrais deste artigo é o de suscitar questões a respeito da pertinência de incluir o setor saúde nessa linha de reflexão e pesquisa, até agora circunscrita ao âmbito dos interesses empresariais da indústria privada e à articulação destes com segmentos da burocracia estatal. Acredito que tal ampliação não é somente adequada, mas também de todo oportuna e necessária. Aliás, um dado essencial para a compreensão do policy-making setorial é, justamente, a existência de um governo dos interesses privados hoje desafiado pela redefinição das relações público/privado que visa submeter esses interesses ao império da regulação pública. Quer dizer, estaria se tentando colocar essa relação nos mesmos termos salientados pelas análises dos neocorporativistas: um dos traços mais conspícuos das democracias contemporâneas é a formulação de pactos entre agentes públicos e representantes das associações pri-

11 E. Diniz e R. R. Boschi, “A Consolidação Democrática no Brasil: Atores Políticos, Processos Sociais e Intermediação de Interesses", in E. Diniz, R. R. Boschi e R. Lessa, Modernizaçāo e Consolidaçãe..., op. cit., p. 60. 
vadas, por meio dos quais os segundos se comprometem a assumir responsabilidades quanto à execução das políticas e a assegurar a adesão dos representados às decisões negociadas, em uma perspectiva de compromisso ético regida pela autoridade estatal.

Nessa linha de raciocínio, minha hipótese é a de que muitas das dificuldades por que passa o setor saúde brasileiro podem ser atribuídas ao fato de que a Reforma Sanitária gestada em 1986, embora negociada quando das mudanças constitucionais e elaboração das leis posteriores, não foi (nem é ainda) presidida por quaisquer acordos formais explícitos entre os principais atores organizados envolvidos, de forma tal que tivessem sido negociados ganhos e perdas e minimamente asseguradas as condições de êxito das estratégias previstas. Certamente, esse fato tem sido prejudicial à eficácia da política em curso.

\section{Associações de interesse no setor saúde}

A constelação de grupos de interesse que se organizaram no setor saúde segue um padrão que não escapa ao modelo mais geral evidenciado nas relações Estado-sociedade civil no País. Entretanto, devem ser assinaladas particularidades relevantes com relação à forma pela qual os interesses setoriais têm se organizado e se feito representar vis-à-vis as políticas de saúde e os espaços públicos abertos à participação dos atores envolvidos no policy-making.

\subsection{Notas sobre a evolução do setor saúde}

Com a criação do Departamento Nacional de Saúde Pública, em 1923, e o desenvolvimento da Previdência Social por meio das Caixas de Aposentadorias e Pensões - CAPs no mesmo ano, e dos Institutos de Aposentadoria e Pensões - IAPs nos anos 30, configura-se no Brasil um setor saúde formado por três áreas: a medicina estatal ou saúde pública, a medicina previdenciária ou curativa e a medicina liberal privada, que já na década de 10 detinha $60 \%$ dos leitos hospitalares do País. ${ }^{12}$

12 M. E. Labra, El Sistema de Servicios de Salud del Brasil, trabalho apresentado no seminário Revisión de los Sistemas de Seguridad Social en América Latina. Participación del Estado y Rol del Sector Privado, Santiago, Chile, Instituto Interamericano de Seguridad Social/Cámara Chilena de la Construcción, 28-31 de março de 1993. 
A atenção à saúde ficou, assim, cindida em três subsetores que nunca haverão de se reconciliar, posto que seguiram lógicas políticas, técnicas, organizacionais e operacionais diferentes. Mais ainda, de acordo com a teoria, a doutrina e a lei, tais setores deveriam ter sido complementares e sujeitos a mecanismos de regulação e controle por parte do Poder Público. Mas o que se observou foi a autonomia de cada área em relação às outras, a simbiose entre a assistência médica da Previdência Social e segmentos do empresariado médico privado contratado por esta, e a interiorização do controle fiscal em cada uma das partes.

A partir de 1930 a saúde pública ficou a cargo do Ministério da Educação e Saúde (Ministério da Saúde desde 1953) e dos respectivos Departamentos de Saúde dos estados e municípios. Contrariamente ao esperado, houve uma involução quanto ao papel técnico-político que nos anos 20 se esperava cumprisse a medicina estatal nos planos nacional e local. De fato, a saúde pública continuou a desempenhar as tradicionais funções assistenciais relativas ao cuidado dos indigentes, contagiosos, crônicos, alienados etc. e a executar campanhas educativas e de combate a moléstias específicas mediante programas verticais isolados, paralelamente à produção, em pequena escala, de soros, vacinas e outros imunobiológicos. Com a criação do Serviço Especializado de Saúde Pública - SESP, em plena Segunda Guerra Mundial, reforça-se esse modus operandi, consolidando-se tanto a separação entre as políticas de cunho preventivo e curativo quanto a burocratização e verticalização das repartições sanitárias.

Já a assistência médica curativa individual destinada à massa trabalhadora urbana ficou, a partir de 1930, adscrita ao Ministério do Trabalho, Indústria e Comércio (e nos anos 70 ao Ministério da Previdência e Assistência Social). Porém, os serviços assistenciais mantiveram-se relativamente autônomos em relação ao governo central, fragmentados nas instituições previdenciárias das respectivas categorias e em extremo dependentes de convênios com a medicina privada, dado o escasso número de estabelecimentos próprios.

Esse quadro muda, parcialmente, na vigência do regime autoritário, quando se efetiva a unificação dos IAPs no Instituto Nacional de Previdência Social - INPS, em 1967. As duas lógicas existentes, porém, são ratificadas pelo Decreto-Lei $n^{\circ} 200 / 67$ : a saúde pública é mantida no setor tradicional do Estado como aparelho centralizado dependente do Tesouro Nacional, enquanto a medicina curativa fica no âmbito descentralizado a cargo do INPS, autarquia financiada pelas contribuições previdenciárias. 
Seria demasiado ressaltar que a criação do INPS significou a montagem de uma imensa, intrincada e insulada burocracia que, a partir de então, se tornou cada vez mais frondosa e poderosa, tanto em termos nacionais quanto internacionais. Sustentada pelos quantiosos recursos oriundos das contribuições, passou a servir como arena privilegiada para o intercâmbio de favores clientelistas e arranjos fisiológicos entre burocratas e políticos. Paralelamente, o Ministério da Saúde, não obstante suas vitais funções de planejamento e regulação e de vigilância sanitária, veio a ser contemplado ínfimamente quando da distribuição de recursos financeiros pelo Executivo. Isso, e mais a centralização das receitas tributárias das unidades federadas na União, foram fatores que contribuíram para acentuar a burocratização e ineficiência dos serviços de saúde pública.

Em fins dos anos 70, a política médico-assistencial ganha novo impulso e autonomia ao serem desmembradas no interior do complexo previdenciário as atividades relativas aos cuidados médicos dos segurados (posteriormente estendidos a toda a população). Para tanto, foi criado, em 1977, o Instituto Nacional de Assistência Médica da Previdência Social - INAMPS, que justamente vai significar a diferenciação institucional da lucrativa área de atuação do empresariado médico-hospitalar privado, enquanto parceiro majoritário e poderoso cliente preferencial do setor público, cujos encargos tiveram inusitada expansão com a universalização dos benefícios.

Um outro momento de mudança importante surge com a transição democrática nos anos 80 , que invade as políticas sociais e cuja tradução na área da saúde se dá por meio da Reforma Sanitária, que visava, justamente, democratizar, unificar e agilizar, mediante a descentralização e municipalização, o sistema como um todo e submeter o setor assistencial privado ao primado da esfera pública. A Reforma plasma-se na Constituição de 1988, na Lei Orgânica da Saúde (n $\left.{ }^{\circ} 8.080 / 90\right)$, que cria o Sistema Unico de Saúde - SUS, e na junção/extinção do Ministério da Saúde - INAMPS em 1992, apontando para um movimento em curso que pretende - com enormes dificuldades e baixíssima visibilidade - superar e fundir as duas racionalidades que no âmbito estatal se desenvolveram ao longo dos últimos 60 anos da história do País.

Por outro lado, o segmento da medicina liberal privada que, desde meados dos anos 60, vinha paulatinamente se diferenciando do subsetor conveniado com a Previdência, nos anos 80 entra em um decidido processo de diversificação empresarial que transcorre segundo a lógica do mercado concorrencial, configurando uma área autônoma em relação ao financiamento público, às políticas de saúde e ao SUS. 
Este breve esboço serve de pano de fundo para melhor situar as associações de interesse que foram se configurando em um setor que, de relativa simplicidade inicial, se transformou em um vasto complexo médico-industrial com transações e interseções que alcançam todos os âmbitos da economia e da sociedade.

\subsection{Panorama do associativismo setorial}

Em termos gerais, o associativismo no setor saúde exibe características que lhe são próprias mas, como veremos, o Brasil representa um caso com especificidades singulares. No plano das profissões, um traço fundamental tem a ver com a profissão médica, que é nuclear em todo o processo de trabalho relativo aos cuidados com a saúde, à qual se subordinam todas as demais profissões e ocupações nesse campo. Esse fenômeno, específico de uma profissão que lida com a vida e a morte, se reflete tanto na forma como se organiza internamente a produção de serviços de saúde, quanto na própria hierarquização das organizações profissionais, e até na forma de associação adotada.

Entre nós, a corporação médica foi a primeira profissão liberal a associar-se em bases modernas ao criar o Sindicato dos Médicos do Brasil, em 1927, seguramente seguindo o modelo francês então em voga. Isto quer dizer que tal formato é anterior ao corporativismo varguista. ainda que posteriormente possa ter passado a se reger pelos cânones impostos a esse tipo de organização gremial. ${ }^{13}$

Mas o traço mais importante da dinâmica associativa é que tanto os médicos quanto os outros profissionais de saúde (odontólogos, enfermeiras, farmacêuticos etc.) se organizaram em três formatos diferentes, quais sejam. o Sindicato, a Associação e a Ordem ou Conselho, o que mostra a vigência da legislação dos anos 30 também no âmbito das profissões. Ao Sindicato compete a defesa dos direitos trabalhistas e à Associação cabe velar por honorários justos para os profissionais liberais, registrar as sociedades de especialidades e promover a atualização científica. Já o Conselho, além de velar pela ética, tem a prerrogativa de credenciar os profissionais para poder ingressar no mercado de trabalho, detendo, portanto, esse órgão, o monopólio da afiliação compulsória.

13 Originalmente os idealizadores do Sindicato dos Médicos do Brasil pretendiam que o mesmo fosse uma única entidade nacional representativa de toda a categoria e de todos os seus interesses (ver, também, nota 16). 
A configuração do associativismo profissional se deu a partir dos estados, passando a constituir, cada uma dessas três formas, uma entidade nacional. No caso dos médicos temos o Conselho Federal de Medicina ou Ordem dos Médicos (1945), a Associação Médica Brasileira (1952) e a Federação Nacional dos (Sindicatos) Médicos (1975). ${ }^{14}$ Até hoje essas representações nacionais (assim como as das outras profissões de saúde) se mantêm separadas. De fato, nunca chegaram a se unir em uma organização centralizada com representação monopólica dos interesses de cada categoria nem, muito menos, em uma confederação das associações de todos os profissionais ou, ainda, em uma representação nacional de todos os trabalhadores de saúde. ${ }^{15}$

Esse traço - representação dividida ou tricotômica - tem efeitos deletérios sobre a coesão interna da categoria e a mediação de demandas dos profissionais junto ao governo e, o mais importante para nós, em relação à vocalização pública e legítima dos associados (e não apenas dos dirigentes de turno) em apoio a políticas que visem favorecer a população, como é o caso do SUS. Além disso, no plano interno, essa divisão cria problemas esdrúxulos no que se refere às competências de cada órgão: por exemplo, enquanto o Conselho de Medicina processa médicos indiciados por erros de responsabilidade profissional, o Sindicato os defende por intermédio de seu setor jurídico!

É importante frisar que esse formato é atípico. A literatura sobre sistemas comparados de saúde e associativismo setorial revela que a tendência é a constituição de poderosas organizações unitárias de caráter nacional, que cumprem funções vitais no policy-making, fundamentalmente em conjunturas de crise e reforma. Existem exceções, como o caso da França, onde a Confederação de Sindicatos Médicos - CSMF dividiu-se nos anos 60, dando origem à Federação dos Médicos - FMF. Mas há consenso em que um traço universal é a existência nos diferentes países de um monopólio profissional fortemente organizado que controla a entrada na profissão, os termos de serviço, formas de propaganda, procedimentos disciplinares etc. ${ }^{16}$ Como

14 No caso do Rio de Janeiro, a afiliação a cada uma dessas instâncias seria a seguinte: Sindicato $-15 \%$ (votam 5\%): Associação - 40\%: Conselho Regional - $100 \%$ (informação fornecida pelo presidente do SinMed-RJ, Luiz Tenório. em 15/9/1992)

15 Recentemente apareceu na imprensa uma "mensagem" assinada pelas associações de representação nacional do empresariado da medicina privada e pela Confederação Nacional dos Trabalhadores na Saúde - CNTS, entidade totalmente desconhecida até agora (ver nota 40).

16 A. J. Culyer, "The NHS and the Market", in G. McLachlan e A. Maynard, eds., The Public/Private Mix for Health, Londres. The Nuffield Provincial Hospitals Trust, 1982, p. 37. Via 
exemplos paradigmáticos dessa característica da organização profissional, podemos citar a Associação Médica Americana - AMA ou, no nosso continente, o Colégio Médico do Chile. Quer dizer, o fenômeno é similar apesar de tratar-se de dois contextos muito diferentes: no primeiro, a medicina liberal tem sido proverbial, ainda que coexista com serviços assistenciais públicos, voluntários e outras modalidades; já no segundo, mesmo após a privatização parcial, em 1981, da atenção à saúde, integralmente estatal até então, o Colégio continuou a deter a representação dos médicos. ${ }^{17}$

Esses exemplos indicam que a peculiaridade do caso brasileiro pode ser atribuída apenas em parte a fatores tais como a herança do corporativismo estatal, a configuração de um sistema de saúde historicamente assentado na tricotomia saúde pública/assistência previdenciária/medicina privada e a existência de um mercado de trabalho heterogêneo com multiplicidade e superposição de vínculos empregatícios. A explicação política, sociológica e jurídica para o fenômeno do associativismo profissional no Brasil não é simples e deverá ficar por conta de futuras pesquisas sobre o tema.

Uma outra dimensão das organizações de interesse é a representada pelos grupos das indústrias farmacêutica e de equipamentos e material médico-hospitalar. Apenas para fins de ilustração, registro a Associação Brasileira da Indústria Farmacêutica - Abifarma criada em 1948. Como se sabe, esta área industrial é a mais internacionalizada da economia. A transnacionalização dessa indústria, que se desenrola nos anos 40 e decisivamente nos anos 50 e 60 com a revolução químico-farmacêutica realizada nos países de capitalismo avançado, levou a uma predominância dos poderosos laboratórios multinacionais que aqui vieram se instalar. Tal fato teve implicações para os órgãos nacionais de representação como a Abifarma, a qual passou

de regra, as associações médicas (e profissionais em geral) são de afiliação compulsória e têm encargos formais tais como: representar e defender os interesses da categoria; velar pelos ideais da medicina liberal; elaborar normas de ética médica, zelar pelo seu cumprimento e julgar as infraçōes; controlar o exercício profissional; estabelecer diretrizes sobre o escopo do conhecimento médico e a formação profissional; credenciar especialidades médicas; estipular e controlar honorários; reivindicar questões salariais, trabalhistas etc.

17 O Colégio Médico de Chile cumpriu todas as funções mencionadas na nota anterior desde 1942 até 1979 , ano este em que a ditadura militar o transformou em associação gremial voluntária, retirando-lhe suas históricas prerrogativas. Todavia, pelo menos $93 \%$ dos médicos continuam afiliados ao Colégio. Com a redemocratização do país a entidade está tentando retomar seu tradicional status e seu papel de ator técnico-político privilegiado quanto ao comando e tomada de decisão nos assuntos da categoria e do setor. Cf. M. E. Labra, "Política, Medicina e Intereses en Chile. Los Impactos de la Privatización y Municipalización en el Asociacionismo Sectorial", Cuadernos Médico Sociales, Rosario, Argentina (no prelo). 
a refletir o peso de seus novos associados, fabricantes de mais de $80 \%$ de todos os produtos farmacêuticos do País. O virtual desaparecimento do empresariado nacional não impediu, todavia, sua reagrupação em 1985 por intermédio da Associação dos Latoratórios Nacionais - Alanac.

Não obstante as imensas necessidades que o setor de medicamentos apresenta em termos de produtos de custo acessível para a população (para mencionar apenas o problema mais ingente), ainda é cedo para antever quaisquer mudanças que possam vir a ameaçar o anel de ferro que se estabeleceu entre os interesses representados na Abifarma $e$ as diversas agências da burocracia estatal, mais afinadas com aquela do que com o interesse geral desde pelo menos os anos 50, quando se instaura o Conselho Consultivo Técnico do Governo/Abifarma.

Ainda no segmento industrial figura a Associação Brasileira da Indústria de Artigos e Equipamentos Médicos, Odontológicos, Hospitalares e de Laboratório - Abimo, criada em 1964 em São Paulo. Esta organização é a única do gênero no ramo, detendo, portanto, o real monopólio da representação desse vasto segmento do capital produtor de tecnologia em saúde. Por motivos que têm a ver com a legislação em vigor, em 1974 configuramse sindicatos estaduais com idêntica designação, os quais passaram também a integrar a Abimo. ${ }^{18}$

Quanto à forma pela qual se organizam os prestadores diretos ou indiretos de serviços de assistência médica no Brasil, na seção seguinte veremos de perto sua evolução. Cabe apenas adiantar que constituiu-se no País, como é bem sabido, um mix público/privado, por um lado, e um segmento autônomo em relação ao INAMPS, de configuração heterogêna e pouco conhecida na sua dinâmica interna, por outro. $\mathrm{O}$ setor privado contratado adquiriu grandes proporções graças à opção política pela prestação de cuidados médicos via compra de serviços profissionais e institucionais particulares, e também em virtude da concessão de subsídios fiscais destinados à expansão física da rede privada. O setor assistencial autônomo, por sua vez, tem encontrado terreno fértil para crescer em conseqüência da incapacidade de o setor público atender à demanda dos usuários de rendas mais altas por serviços eficientes e de boa qualidade. Daí que as diversas modalidades de programas e planos de saúde privados sejam uma alternativa real para essa faixa populacional.

18 Informaçōes obtidas em setembro de 1992. junto à matriz da Abimo em São Paulo. 
Como observação geral ao associativismo empresarial verifica-se que também este apresenta um formato híbrido ou dual (sindicato e associação), além do que, como veremos adiante, no âmbito da medicina de grupo surge, mais recentemente, a forma conselho para zelar pela ética nos negócios desse segmento.

Dada a predominância do setor privado de saúde no País, não é por acaso que suas organizações nacionais de interesse alcançaram a liderança no âmbito dos países latino-americanos empenhados em privatizar seus serviços de saúde. De fato, fundaram, em 1980, a Associação Latino-Americana de Medicina Integral - ALAMI, que congrega os sistemas privados. ${ }^{19} \mathrm{O}$ Brasil também ocupa lugar de destaque no contexto mundial, perdendo apenas para os Estados Unidos, país onde a medicina liberal privada, há tempos, se encontra empresariada e organizada em poderosas associações monopólicas como a American Hospital Association - AHA.

A visão geral e ainda incompleta do associativismo setorial nos permite coligir que se trata de um universo bastante complexo, denso e diversificado. Mas o problema complica-se de forma inusitada se considerarmos as associações de interesse regionais, estaduais e municipais. Há que se ressaltar que a dimensão mesolocal, de grande relevância nas regiões metropolitanas, adquire importância cada vez maior à medida que a descentralização do sistema de saúde avança. A esse respeito, é de se supor que conforme descendem os níveis de decisão política, igualmente far-se-á necessário focalizar as pesquisas em unidades de análise acordes com os novos níveis de agrupação e ativação de interesses.

Como item último desta seção, farei referência aos espaços oficiais abertos à participação de atores setoriais.

\subsection{A representação na esfera pública}

A existência de espaços oficiais abertos à participação retórica ou real de representantes dos interesses da saúde é de longa data. Além do fato histórico de as próprias repartições de saúde pública terem se originado das Juntas de Higiene do século XIX, pode ser lembrado, por exemplo, o Conselho Nacional de Saúde Pública, criado no bojo da Reforma Sanitária de 1923 e integrado por notáveis da época. ${ }^{20}$

19 A iniciativa foi de Luiz Antonio Sampaio Dória, presidente da Interclínicas do Brasil, sediada em São Paulo. Cf. Informe Final del V Congreso da ALAMI, Sistemas Privados de Salud, Viña del Mar. Chile. 29-31 de outubro de 1990.

20 Para a composição desse Conselho e os arranjos em torno de sua instalação, ver M. E. Labra, 
Após os anos 30 tais arenas foram recriadas de forma intermitente sob a figura de Conselhos ou Comissões, tanto no âmbito da saúde pública quanto da previdência social, seja com intuitos legitimadores, racionalizadores ou democratizantes. Mas, mesmo no interregno liberal-democrático dos anos 1946-63, as experiências de decisões compartilhadas não vingaram, sendo estéreis os esforços que porventura existiram para imprimir rumos diferentes e mais eqüitativos às políticas de saúde.

Quanto ao presente, um elemento constitutivo da nova racionalidade político-institucional legislada para o setor são os Conselhos de Saúde (nacional e locais) - colegiados de caráter permanente e deliberativo, compostos paritariamente por representantes do governo, prestadores de serviços e profissionais de saúde (50\%) e dos usuários $(50 \%)$. Estão destinados formalmente a atuar na formulação de políticas e no controle da execução. Tratarse-ia, em conseqüência, de um locus privilegiado para a negociação, a resolução de conflitos e o acordo entre partes.

Porém, um ponto óbvio que a priori me inquieta em relação à composição dos Conselhos tem a ver justamente com a pergunta: quem representa o que e a quem? Quem representa os difusos interesses dos usuários? Quais são os incentivos que estes teriam para participar da ação coletiva inerente à representação organizada? Os usuários, enfim, constituem uma coletividade ou, em termos sócio-políticos, um grupo de interesse? Voltarei a estes pontos no encerramento da minha exposição.

\section{Organizações do empresariado médico-hospitalar brasileiro}

Nesta seção pretendo apenas descrever alguns aspectos da evolução e configuração das associações do empresariado privado da medicina.

Como mostra o quadro em anexo, as organizações que povoam o mercado da saúde são numerosas. Mas, além disso, são muito poderosas, tendo em vista o peso de suas atividades e o volume financeiro de seus negócios. De acordo com seus porta-vozes, o setor privado (lucrativo e não-lucrativo) é proprietário de $74 \%$ dos estabelecimentos com internação e de $77 \%$ dos leitos, e é responsável por mais de $80 \%$ das internações hospitalares e $46 \%$ dos atendimentos ambulatoriais no País; o segmento autônomo do Estado cobre 32 milhões de pessoas e seu faturamento foi de US\$ 2,5

O Movimento Sanitarista nos Anos 20. Da "Conexão Sanitária Internacional" à Especializaçāo em Saúde Pública, Tese de Mestrado em Administração Pública, EBAP/FGV, 1985. 
bilhões em 1989; o governo gasta, por sua parte, mais de US\$ 2 bilhões anuais em serviços contratados com a rede privada lucrativa. ${ }^{21}$ Depreende-se desses dados que o mercado de serviços de saúde é realmente importante no Brasil, e poderia ser muito maior não fosse o baixíssimo poder aquisitivo da grande maioria da população.

Antes de entrar na individualização das associações, apontarei alguns aspectos gerais que poderão ajudar na compreensão do universo sob estudo.

$\mathrm{Na}$ área assistencial atuam numerosos grupos de interesse que organizam a representação de seus membros de acordo com critérios tais como: forma de inserção no mercado, natureza dá atividade dos associados, tipo de clientela atendida, fins lucrativos ou não e peso geográfico dos interesses.

Ao longo do tempo, as associações tendem a conglomerar-se em uma entidade nacional específica mediante um processo nem sempre muito claro, mas que mostra alguns traços importantes. Há superposições na afiliação às organizações nacionais porque um membro singular pode ter duas ou mais inserções no mercado. Em geral as organizações mais antigas têm sido compelidas pela competição em um mercado bastante saturado a incorporar outras categorias de membros com perfis diferentes daqueles que originaram a associação. Existem numerosas exclusões por razões difíceis de determinar por enquanto, mas que se observam sobretudo em segmentos de mercado de criação mais recente.

De outro lado, também no âmbito do empresariado médico confirma-se o dualismo do associativismo brasileiro, como é o caso dos sindicatos de donos de hospitais criados sob o corporativismo estadonovista, que passam a conviver com associações de origem societal que congregariam, em tese, o mesmo universo de membros. Já no caso da medicina de grupo observa-se processo similar, mas com uma importante adição: cria recentemente a figura do Conselho, o qual vem confirmar o formato de representação tricotômica apontado para as profissões.

Reitero, por último, que em relação aos pontos até aqui levantados e outros tais como o tamanho, a lógica interna de cada uma dessas associações, as articulações entre elas, a relação entre cúpulas e membros, as transformações pelas quais têm passado (inclusive a extinção de formas intermediárias),

21 Exposiçōes dos delegados brasileiros no Relatório Final do V Congreso de ALAMI..., op. cit. Os dados aproximam-se dos levantados por mim em El Sistema de Servicios..., op. cit.; ver, também, A. Médici, "O Setor Privado Prestador de Saúde no Brasil", Relatórios Técnicos, $\mathrm{n}^{\circ}$ 2, Rio de Janeiro, ENCE/IBGE, 1990. 
bem como seus modos de ação coletiva, são problemas que aqui não abordarei.

Para fins de exposição distinguirei cinco tipos ou segmentos: (a) prestadores lucrativos; (b) prestadores filantrópicos; (c) empresariado autônomo; (d) sistemas fechados; (e) seguradoras.

(a) Prestadores lucrativos. A meu ver, o interesse comum fundamental que originalmente levou os proprietários de estabelecimentos de saúde a se associarem foi não somente o fato de o setor privado da medicina liberal ser hegemônico no País, já no começo do século, senão também a expectativa com relação ao mercado potencial de compra e venda de serviços aberto pelos institutos previdenciários. O movimento de agregação começa em 1938 com a criação do Sindicato dos Donos de Hospitais - Sindhosp, primeiro em São Paulo (que vai liderar todo o subseqüente processo associativo no País) e depois nos outros estados, nos moldes da estrutura corporativa da época e com "o intuito de colaboração com os poderes públicos e as demais associações no sentido de solidariedade social e da sua subordinação aos interesses nacionais". ${ }^{22}$ Atualmente existem no País 25 sindicatos de donos de hospitais.

Nos anos 50 surge a Associação Brasileira de Hospitais já dentro da lógica de independência da representação em relação à tutela estatal, ou seja, sua origem é societal. Em seu II Congresso, em 1955, essa associação demonstra preocupação por definir fluxos permanentes de financiamento e padrões de remuneração dos serviços prestados aos institutos previdenciários, tema que, em definitivo, será o grande leitmotiv do empresariado médico contratado. ${ }^{23}$

Em 1965 alguns hospitais paulistas iniciaram contatos com a finalidade de estudar problemas comuns relacionados com a venda de serviços aos institutos, sendo criada então a Associação dos Hospitais que Prestam Serviços à Previdência Social, ${ }^{24}$ transformada no ano seguinte na influente Associação de Hospitais do Estado de São Paulo. Criaram-se, a seguir,

22 Artigo $1^{\circ}$ do estatuto da entidade, redigido segundo o padrão estabelecido em 1939 pelo Departamento Nacional do Trabalho. Apud A. Cohn et alli, O Setor Privado e as Políticas de Saúde na Atual Conjuntura Brasileira (1978-1990), Relatório de Pesquisa, São Paulo, Centro de Estudos Augusto Leopoldo Ayrosa Galvão, 1991, p. 47.

23 Notas pessoais de pesquisa tendo como base os Anais do II Congresso da Associaçāo Brasileira de Hospitais, Belo Horizonte, 1955

24 Apud J. de A. Oliveira, Interesses Sociais e Mecanismos de Representação: A Política de Saúde no Pós-64, Relatório de Pesquisa, Rio de Janeiro, Fiocruz/ENSP/DAPS, 1982, p. 56, mimeo. 
agremiações similares em vários outros estados e regiões, como a Associação Nordestina de Hospitais Particulares.

Esse processo de agregação culmina, em 1966, com a fundação no Rio de Janeiro da Federação Brasileira (de Associações) de Hospitais - FBH. organização esta que é a principal do País. A criação da FBH obedeceu a um objetivo primordial que continua vigente: a necessidade de os proprietários de hospitais contarem com um instrumento de pressão sobre o Estado em matéria de preços e tarifas. É interessante registrar as finalidades estatutárias da FBH porque revelam com clareza as funções de representação monopólica de seus membros, de exclusiva interlocução junto aos poderes públicos e de ousada intermediação clientelista e de pressão personalista que se propusera a cumprir:

"Representar as Associações Federadas perante os órgãos da Previdência Social e demais órgãos Federais, Estaduais e Municipais e de iniciativa privada, que de qualquer forma possam interferir na Assistência Hospitalar; Influir junto aos órgāos competentes, para que os hospitais sejam considerados como instituiçōes primordiais para o desenvolvimento e bem-estar da Nação e para que a política econômica, financeira e tributária dos governos venha favorecer o aprimoramento e ampliação dos mesmos; Influir [o Presidente] pessoalmente ou por terceiros, para que nenhuma decisão seja tomada pela Previdência Social e demais órgãos, sem que a Federação seja ouvida." 25

A FBH tem várias categorias de sócios: hospitais e casas de saúde; sanatórios e postos de saúde; associações de classe; clínicas, prontos-socorros e ambulatórios; e pessoas físicas. Originalmente, só congregava a primeira categoria a qual, ainda hoje, é a única que tem direito a voto e a cargos eletivos na direção da associação. ${ }^{26}$

A FBH congrega, atualmente, 20 associações estaduais. Seu lema é a defesa intransigente da livre iniciativa, opondo-se a qualquer tentativa de estatização da assistência médica. Sua força reside no fato de seus sócios serem os maiores vendedores de serviços ao setor público e de deterem a propriedade de quase $50 \%$ dos estabelecimentos hospitalares particulares do País. ${ }^{27}$

Cabe mencionar que, em 1983, a FBH ganhou um importante aliado com a criação da Federação Nacional de Estabelecimentos de Serviços de

25 Idem, pp. 57-8. É interessante notar que a diretoria da FBH oferecia uma série de incentivos seletivos para impulsionar a formaçâo de organizaçōes e a afiliação de membros. tais como assessoria direta, informações científicas, técnicas e administrativas, troca de experiência etc. por meio da revista Vida Hospitalar.

26 A. Cohn et alli, O Setor Privado e.... op. cit. p. 60.

27 Dados do IBGE para o ano 1985. Cf. A. Médici, “O Setor Privado...". op. cit. 
Saúde - Fenaess, que congrega os donos de clínicas com e sem internação, laboratórios de análises e de radiodiagnóstico. ${ }^{28}$

(b) Prestadores filantrópicos. Este grupo é ilustrado pelas Santas Casas de Misericórdia, que representam o que há de mais antigo e tradicional no mundo ocidental em termos de ajuda e assistência aos doentes pobres. Assentadas no princípio da caridade cristã que está nas suas origens, formam, em 1958, a Federação das Misericórdias. Em 1963 agregam-se na Confederação das Misericórdias e empreendem um processo de modernização para enfrentar a elevação dos custos médicos. Nos anos 70, enfim, as Santas Casas atualizam seus objetivos, passando a considerar a atenção médica como sua principal atividade, para assim melhor concorrer com o setor lucrativo na venda de serviços à Previdência Social. A Confederação conta com 250 filiadas agrupadas em 10 representações regionais subordinadas a um coordenador geral. ${ }^{29} \mathrm{~A}$ importância relativa das Santas Casas no mercado de saúde cresceu de meados dos anos 80 em diante mas, mesmo assim, seu peso no conjunto dos prestadores privados mantém-se muito limitado pois possui somente $16 \%$ dos estabelecimentos.

(c) Empresariado autônomo. Nos anos 50 e 60 inicia-se a organização das empresas de medicina de grupo, que se apresentarão como a grande alternativa aos serviços contratados pela Previdência Social na atenção à saúde dos operários das indústrias de ponta do $\mathrm{ABC}$ paulista. A primeira entidade representativa dos novos interesses foi a Associação Médica de São Paulo Amesp, criada em 1959.

Em 1966, 80 empresas médicas formaram a Associação Brasileira de Medicina de Grupo - Abramge. A entidade pretendia, no início, prestar atendimento preferencial à força de trabalho mais qualificada da indústria e das grandes empresas de serviços, financeiros em particular. Tal tendência muda na década seguinte quando, esgotado esse mercado, os membros da Abramge passam a celebrar convênios com empresas de médio e pequeno portes. A nova modalidade assistencial contou com a adesão de numerosos profissionais, que formaram a Associação Nacional dos Médicos que Exercem em Grupo. O presidente desta, aliás, desempenhou importante papel na

28 Informaçōes obtidas em setembro de 1992 junto a gerência da Fenaess, em São Paulo.

29 Os incentivos seletivos oferecidos pela Confederação das Misericórdias são, entre outros: realização de encontros e cursos de atualização; assessoria nas áreas de informatização de hospitais, engenharia, arquitetura e sistemas de compras. A. Cohn et alli. O Setor Privado e..., op. cit. pp. 65-73. 
divulgação, em 1972, de informações sobre as diversas formas de exercício da medicina em cooperação existente na França. ${ }^{30}$

A medicina de grupo opera majoritariamente mediante contratos com terceiros (apenas $36 \%$ das empresas deste segmento têm serviços próprios) e em 1990 contava com mais de 15 milhões de beneficiários. O grupo mais importante do País afiliado à Abramge é a Golden Cross, que nos anos 90 começa a operar também no ramo de seguros.

Embora a Abramge seja a principal associação dos grupos médicos no plano nacional, é importante frisar que representa somente cerca de $45 \%$ do contigente de empresas desse tipo. Por outro lado, as afiliadas à Abramge se fazem também representar por dois outros órgãos: pelo Sindicato Nacional das Empresas de Medicina de Grupo - Sinamge (para representação judicial) e, nos anos 90, pelo Conselho Nacional das Empresas de Medicina de Grupo - Conamge, responsável pelo controle ético e qualitativo dos serviços e a seleção dos membros segundo padrões técnicos e financeiros rigorosos. ${ }^{31}$ Esse Conselho, enquanto terceira forma de associação para o mesmo grupo de interesse, foi encontrado somente nesse caso, mas estaria a ratificar a possibilidade da representação tricotômica, já aludida, também na área empresarial.

Uma outra modalidade que surge em 1967 como alternativa à "exploração dos médicos pela medicina de grupo" é o das cooperativas médicas ou Sistema Unimed (União dos Médicos). A UNIMED se assume como entidade representativa da categoria médica por defender e cumprir os direitos trabalhistas, enquanto no mercado oferece planos de pré-pagamento ao alcance da classe média.

O Sistema Unimed compreende três níveis de organização: as cooperativas singulares, as federações com abrangência regional ou estadual e, em âmbito nacional, a Confederação das Unimeds, criada em 1983 e que hoje assegura cerca de 3,5 milhões de pessoas. ${ }^{32}$

30 J. Beaupère, "O Exercício da Medicina em Grupo", Revista da AMB, julho de 1972, traduzido de Le Concurs Médical. As modalidades examinadas são: contrato de exercício em comum, sociedade civil de meios, cooperativas médicas, grupo de interesse econômico e sociedade imobiliária.

31 Segundo palavras do dirigente da Conamge, Paulo S. B. Barbanti, em conferência proferida no $\checkmark$ Congreso da ALAMI.., op. cit.

32 M. de F. S. Andreazzi, O Seguro Saúde Privado no Brasil, Tese de Mestrado em Saúde Pública ENSP/Fiocruz, 1991, p. 229. Ver também A. Cohn et alli, O Setor Privado e..., op. cit. 
Segundo Médici, a medicina de grupo junto com as cooperativas médicas constituem, "provavelmente, as principais formas de fornecimento de serviços de saúde à população no universo das relações capital $x$ trabalho". ${ }^{33}$

(d) Sistemas fechados. As instituições e empresas que administram seus próprios planos de saúde conformam um segmento de difícil identificação, além de heterogêno quanto às atividades que realizam e à natureza jurídica; abrangem os ramos de serviços, indústria e bancário dos setores estatal, privado e misto. $\mathrm{O}$ ponto em comum entre elas é o fato de terem criado serviços, assistenciais para atender reivindicações dos funcionários dos estratos mais privilegiados dos assalariados, dentro do leque de fringe benefits que estes têm conquistado.

A principal entidade nacional que representa esses interesses é a Associação Brasileira dos Serviços Próprios das Empresas - Abraspe,criada em 1980. São afiliadas a ela 119 empresas, que compreendem cerca de 7,5 milhões de beneficiários ${ }^{34}$ Essa Associação apresenta, contudo, importantes exclusões, sendo a Petrobrás um conspícuo exemplo de empresa estatal que possui sistema próprio de saúde para seus funcionários, mas que não é membro dela. De fato, as afiliadas à Abraspe representam apenas um terço da totalidade dos autoprogramas que existiriam no País, os quais, em conjunto, teriam uma cobertura estimada bem maior que aquela: cerca de 22 milhões de pessoas. ${ }^{35}$

Visando agregar futuramente de forma mais definida os interesses dos beneficiários dos programas de autogestão de empresas e instituições públicas e mistas, surge, em 1990, o Comitê de Integração de Entidades Fechadas de Assistência à Saúde - CIEFAS. Entre os seus membros contam-se as associações de funcionários do Ministério da Economia, Banco Central, Banco do Brasil, Banerj, CEF, ECT, Embratel, Petrobrás e muitas mais. Contudo, uma boa parcela das associadas ao CIEFAS também está representada na Abraspe, enquanto outras entidades desse tipo continuam isoladas. ${ }^{36}$

33 A. Médici, "O Setor Privado...", op. cit., p. 21.

34 Os dados são de A. Médici, "Incentivos Governamentais ao Setor Privado em Saúde no Brasil", Relatórios Técnicos, $\mathrm{n}^{\circ} 2$, Rio de Janeiro, ENCE/IBGE, 1991, p. 28. Ver, também, M. Burgos et alli,Público e Privado no Sistema de Saúde Brasileiro: A Contextualização do Debate em torno dos Programas Suplementares no Setor Público, Relatório Final de Pesquisa, Rio de Janeiro, Convênio CEPESC/CASSI, 1991.

35 A. Médici, "Incentivos Governamentais..., op. cit., p. 29.

36 M. Burgos et alli, Público e Privado..., op. cit., p. 94. 
(e) Seguradoras. O ramo de seguros comerciais tem longa data de existência no Brasil. As diversas companhias do País criaram, em 1951, a Federação Nacional de Seguros Privados - Fenaseg. Em 1966 aparece a primeira legislação a respeito do seguro saúde, que será regulamentado somente dez anos depois. Em 1974 surge a Sociedade Brasileira de Medicina de Seguro com o objetivo de congregar os médicos que atuavam junto às seguradoras. ${ }^{37}$ Sucessivas modificações permitiram que o Seguro de Assistência Médica e/ou Hospitalar (assim denominado em 1988) passasse a incluir clientelas cada vez mais diversificadas (indivíduos, famílias, grupos, pessoas jurídicas como sindicatos e associações profissionais), o que se traduziu em um expressivo crescimento dessa modalidade assistencial: $500 \%$ no período 1981 89. ${ }^{38}$ Recentemente a Fenaseg ampliou o escopo de seus associados, incorporando o setor financeiro e mudando sua denominação para Federação Nacional de Seguros Privados e de Capitalização.

Entre as empresas mais relevantes afiliadas à Fenaseg figuram Saúde Bradesco e Hospitaú, às quais veio se juntar a Golden Cross Seguradora. Devido ao seu alto custo e às poucas alternativas que oferece, o seguro saúde é ainda pouco expressivo enquanto modalidade assistencial,mas absorve o estrato das mais altas rendas.

À guisa de encerramento desta seção podemos sintetizar, apontando para algumas tendências importantes mostradas pelo mapeamento realizado:

(a) as associações passaram por um processo de concentração e hierarquização da representação ao nível nacional, sem chegar contudo a configurar uma só organização agregadora de todos os interesses do empresariado privado da medicina;

(b) o formato de organização predominante é dual - sindicato e associação - mas observa-se também, excepcionalmente, a representação tricotômica no caso da medicina de grupo;

(c) o mercado privado de saúde, além de muito heterogêneo, encontrase em pleno processo de especialização funcional e reagrupação/mutação de interesses por fatores atribuíveis à recessão, à crise da medicina previdenciária, às novas políticas de saúde e ao surgimento de regimes assistenciais de tipo fechado;

(d) a expansão de sistemas fechados conformados pelos serviços dos funcionários de grandes instituições e empresas públicas e privadas é um

37 M. de F. S. Andreazzi, O Seguro Saúde..., op. cit., p. 142.

38 Idem, p. 116. 
dado que aponta para o surgimento de novos grupos de interesse em vias de diferenciação interna;

(e) os estratos de maiores rendas do País estariam já cobertos pelas diversas modalidades assistenciais oferecidas pelo mercado, fato que retira poder de pressão aos quase $70 \%$ de brasileiros pobres que dependem da atenção dos serviços públicos próprios ou contratados pelo Estado;

(f) na pesquisa não detectei nenhuma associação nacional de usuários, não obstante seu peso numérico e a relevância legal atribuída à representação desses interesses na formulação e controle das políticas setoriais. ${ }^{39}$

O exame da constelação de organizações empresariais da medicina mostra, enfim, que se trata de um denso universo que abriga interesses cruzados com representação dual e até tricotômica, mas que é liderado por quatro grandes associações nacionais representativas do segmento lucrativo: FBH, Fenaess, Abramge e Fenaseg.

Ainda que a heterogeneidade observada torne as associações presa fácil de agudos conflitos intra e interorganizacionais e com o governo,a situação crítica do setor público assistencial, cujas sérias repercussões institucionais incluem a controvertida extinção do INAMPS, vem servindo de catalisador dos interesses conflitantes. Com efeito, no esteio dessa crise, justamente a FBH, Fenaess, Fenaseg, Abramge/Sinange (junto com uma "fantasma" Confederação Nacional dos Trabalhadores na Saúde) lograram aunar interesses, desenhar uma estratégia de expansão de seu mercado (inspirada na experiência chilena) e apresentar um Plano Básico de Assistência Médica financiado, em parte, pelas contribuições previdenciárias, com vistas a "concretizar o casamento do Estado com a iniciativa privada na complementação do SUS". Propõem, ainda, como solução para o problema da saúde dos brasileiros formar "uma séria aliança, responsável e participativa, dos nossos Governantes Federais, Estaduais e Municipais, dos representantes do povo nas casas legislativas, dos trabalhadores, dos empregadores, e certamente, das empresas e profissionais privados que estão integrados no processo". 40

39 Segundo o Jornal do Brasil de 30/4/1993, os consumidores de serviços privados do Rio de Janeiro formaram recentemente a Associação dos Participantes dos Planos de Saúde Privados e Previdenciários, à qual, apoiada no Código de Defesa do Consumidor, já teria conseguido abolir os contratos com letra miúda.

40 "A Extinção do INAMPS e a Saúde do País: Mensagem ao Presidente da República", Jornal do Brasil, 3-4/5/1993. 
Paradoxalmente, o SUS é, em si, uma estratégia que visa desfazer o casamento do Estado com os interesses privados! E é bem outro o tipo de liderança que uma aliança como a proposta precisaria para que a saúde saísse da crise em que se encontra. Nas reflexões que se seguem voltarei ao assunto.

\section{Considerações Finais}

O setor saúde vive um virtual impasse, porém não somente por causa das crises que castigam o País. A reforma descentralizadora dos serviços também afeta a normalidade institucional e a própria acomodação de interesses, embora não anule a compra de serviços privados nem mude, per se, os valores dos funcionários. Essa reforma é em si um processo extremamente complicado, caro, moroso e incerto que, por sua própria natureza, tende a produzir efeitos não esperados ou indesejados pelos legisladores ou planejadores:

Justamente para reduzir os graus de incerteza e assegurar o controle social é que foram criados os Conselhos Locais de Saúde. Mas a potencial instalação desses colegiados tem levado a uma revolução de expectativas de toda sorte quanto à sua capacidade de realmente mudar traços profundamente arraigados nas instituições do setor, tais como o comportamento aético que tem permeado a relação entre as agências públicas e suas clientelas; a ausência de compromisso dos empresários da medicina e produtores de tecnologia com o interesse geral; o despotismo burocrático no atendimento aos pacientes; e o renitente corporativismo particularista das associações profissionais.

Indago se são esses Conselhos os instrumentos adequados para enfrentar com razoável eficácia política a incomensurável tarefa de alterar as lógicas de poder e os padrões de funcionamento que ao longo de seis décadas foram se enraizando no setor saúde. Questiono até que ponto a composição decidida para esses colegiados responde à realidade do associativismo setorial atual e leva em conta o fato de a burocracia assistencial estatal depender fundamentalmente do setor médico particular para prestar serviços hospitalares aos doentes que não têm acesso às modalidades privadas de atenção, ou seja, a maioria da população. Foi justamente para contrabalançar esses poderosos interesses que os ideólogos da Reforma Sanitária adjudicaram 50\% da representação, do poder de veto e de decisão aos usuários. Mas estes constituem uma categoria muito heterogênea, dispersa e difusa, que não possui os mínimos requisitos para se dotar dos meios organizacionais neces- 
sários à acumulação quantitativa de poder e assim defender qualitativamente os fins aos quais esse poder é aplicado.

A representação paritária concedida aos usuários é uma ilusão: não resolve os reais desequilíbrios que existem entre os interesses dos indivíduos, por um lado, e os das pesadas estruturas de decisão e associação, por outro. Não lembrarei aqui as precondições da ação coletiva, além do já enunciado no início desta exposição. ${ }^{41}$ Apenas observarei que a indução forçada do povo a se organizar somente existe como experiência histórica no corporativismo autoritário - e isso já conhecemos. A organização dos consumidores, contribuintes ou policy-takers, nas raríssimas experiências onde ela tem integrado arranjos de concertação, desenvolveu-se no seio de uma cultura de participação comunitária e tradição de organizações sociais e políticas fortes, além de ter estado acompanhada de certos atributos de prosperidade nacional sustentada. ${ }^{42}$

Segundo Werneck Vianna a marca da sociedade brasileira tem sido a "corporativização" e a fragmentação do corpo social porque "fomos conduzidos à industrialização por meio de uma ideologia avessa à política, aos partidos e ao livre conflito de interesses, [de forma tal que] a opinião, a ideologia portada pelos partidos não teve como se encontrar com o mundo dos interesses". Para o autor, essa separação somente poderá ser superada se removido "o corporativismo da estrutura sindical e da organização da vida das profissões, definindo um campo livre para novas formas de associação que implicam novo tipo de relações entre Estado e sociedade civil". ${ }^{43}$

A história recente do setor saúde parece desafiar o pessimismo desse autor pela inédita convergência da ideologia e do interesse que embasou a mobilização política e social dos brasileiros na luta por rumos novos e democráticos para a política de saúde. Mas essa convergência, hoje fica claro, se desmanchou no ar assim que as mudanças começaram a tocar interesses consolidados, trazendo, além disso, à tona o fato, crucial no meu entender, de que o issue saúde é uma questão no mínimo ambígua tanto para os partidos políticos de base popular quanto para as centrais sindicais, por

41 Para duas contribuições contrastantes a respeito da dinâmica da ação coletiva, ver M. Olson, The Logic of Collective Action, Cambridge, Harvard University Press, 1971 e C. Offe. "A Atribuição de Status Público aos Grupos de Interesse", in Capitalismo Desorganizado, São Paulo, Brasiliense, 1989. Para uma excelente e atual análise do caso brasileiro, ver W. G. dos Santos, Razões da Desordem, Rio de Janeiro, Rocco, 1993.

42 C. Offe, “A Atribuição de...”. op. cit.

43 L. W. Vianna, A Transição..., op. cit., pp. 15-7.

no Brasil, salientando o formato híbrido ou dual da representação. Com base em um quadro sinóptico que ilustra a evolução do associativismo setorial vis-à-vis as políticas de saúde, são examinadas particularidades tais como formatos de representação (dual, tricotômica) e densidade da constelação de associações representativas dos interesses das profissões, dos produtores de tecnologia em saúde e, em particular, do empresariado médico assistencial. Finalmente, em face da maturidade e complexidade do universo analisado, indaga-se a respeito das condições de eficácia política do Conselho de Saúde 
causa do sistema de privilégios engendrado no País. Como lutar por um sistema único, universal e eqüitativo se as elites do operariado. dos empregados e do funcionalismo reivindicam e conseguem serviços assistenciais de qualidade providos pelo setor privado por intermédio de planos de saúde ou de sistemas próprios, fechados?

Mesmo colocado o problema em termos da majoritária população restante, ou seja os pobres, continua vigente a necessidade de se levar adiante as reformas no setor. A respeito, e reportando-me a Przeworski, poderia dizer que o que a saúde precisa é de um acordo ou "pacto democrático" que processe uma "transformação alquímica", quer dizer. uma alteração "das condições existentes de maneira tal que a aceitação voluntária e descentralizada seja individualmente ótima. São acordos para permitir a discordância. A única maneria de mudar as condições, por acordo. é estabelecer novas instituiçōes". ${ }^{44}$ Nesse sentido, pergunto: não deveriam essas tarefas ser empreendidas por uma supra-instância tipo câmara setorial, que atuaria segundo uma agenda de pontos a serem negociados - por meio de processos que em uma democracia são sempre complexos. difíceis e lentos - para o logro de consensos mínimos entre as partes?

Acredito que para tanto, no Brasil, as condições organizacionais da representação funcional dos interesses fundamentais do setor (profissionais, empresariados médico e industrial e burocracia especializada) já estão dadas e amadurecidas. Não obstante o peculiar formato de representação dividida (que incide no número de interlocutores legítimos com o governo). uma ação concertada conducente a um acordo é uma probabilidade latente e até real. Aliás, o fomento à concertação pode funcionar como indutor até de esforços para superar essas divisões. Os estudiosos do neocorporativismo têm reiteradamente demonstrado a viabilidade política e prática de tais arranjos em contextos de crise do Estado de Bem-Estar. Como exemplifiquei em um outro texto, mais de 60 representantes dos interesses do setor saúde formaram um conselho permanente na Alemanha nos anos 70, justamente para enfrentar, mediante a Konzertien Aktion, a crise causada pela elevação dos custos da atenção médica pública. ${ }^{45}$

No Brasil, o chamado oportunista à aliança feito pelas associações nacionais do empresariado da medicina é produto de um pacto virtual firmado entre elas, visando maximizar os recursos de poder que já possuem

44 A. Przeworski, "Transiçẫo Democrática e Teoria dos Jogos". Dados, vol. 35. n 1. 1992. pp. 5-48.

45 M. E. Labra, “Politica de Interesses..." op. cit., p. 131. 
individualmente e os benefícios futuros que poderão obter se acolhida a proposta de um Plano Básico de Assistência Médica subsidiado com recursos públicos. Claramente, isso viria diminuir a incerteza imperante no mercado de saúde. Mas o setor privado sabe que tal proposta contraria os princípios da Reforma Sanitária. Esta, apesar de todos os tropeços, conta com forte apoio político e social.

Olhado sob outro prisma, todavia, o chamamento a tal aliança poderia ser considerado como um alerta para se pensar na instauração de um espaço ad hoc que propiciaria o estabelecimento de acordos abrangentes e inclusivos a serem firmados pelo Estado com todos os representantes das organizações setoriais nacionais. Tais acordos deveriam incluir não somente um plano estratégico e tático de mudanças mas, sobretudo, um pacto de moralidade para enfrentar a crise de credibilidade ética que grassa no setor, num marco de restauração do enforcement estatal e da regulação pública diante do desgoverno dos interesses privados na atenção à saúde da população brasileira.

\section{RESUMO}

\section{Associativismo no Setor Saúde Brasileiro e Organizações de Interesse do Empresariado Médico}

O objetivo deste artigo é o de introduzir a reflexão a respeito das possibilidades de construção de um pacto social ou formas de concertação entre os atores organizados do setor saúde, tendo em vista a implantação do Sistema Unico de Saúde e seus impasses. A exposição aborda aspectos teóricos colocados pelo enfoque neocorporativo quanto às relações Estadosociedade civil, a dimensão associativa da ordem social, o intercâmbio político entre as esferas pública e privada e a intermediação de interesses organizados no policy-making nas democracias contemporâneas. Passa-se em revista o padrão de organização de interesses estruturado historicamente no Brasil, salientando o formato híbrido ou dual da representação. Com base em um quadro sinóptico que ilustra a evolução do associativismo setorial vis-à-vis as políticas de saúde, são examinadas particularidades tais como formatos de representação (dual, tricotômica) e densidade da constelação de associações representativas dos interesses das profissões, dos produtores de tecnologia em saúde e, em particular, do empresariado médico assistencial. Finalmente, em face da maturidade e complexidade do universo analisado, indaga-se a respeito das condições de eficácia política do Conselho de Saúde 
enquanto instrumento criado para operar transformações estruturais e culturais no sistema de saúde e locus adequado para a concertação coletiva entre os interesses organizados ali representados.

\section{ABSTRACT \\ Associativism in the Brazilian Health-care Sector and Interest Organizations in the Medical Industry}

The article reflects on the chances of constructing a social pact, or forms of concertation, among organized actors in the health sector, in light of implementation of the Unified Health-care System [Sistema Unico de Saúde] and of associated impasses. The discussion addresses theoretical aspects raised by the neocorporatist perspective regarding state/civil society relations, the associative dimensions of the social order, political exchange between the public and private realms, and the mediation of organized interests in policy-making within contemporary democracies. In an overview of the pattern of interest organization as historically structured in Brazil, the hybrid, or dual, format of representation is highlighted. By reference to a synoptic table illustrating the evolution of sectorial associativism vis-à-vis that of health policies, an examination is made of such characteristics as representation formats [dual, trichotomic] and the density of the constellation of associations representing the interests of professions, the producers of health technology, and, in particular, the medical/health-care industry. Lastly, given the stage of maturity and complexity of the universe under analysis, questions are raised as to the potential political efficaciousness of the Health Board [Conselho de Saúde] as an instrument meant to achieve structural and cultural transformation within the health-care system and as to whether it is the most suitable locus for the collective concertation between the organized interests represented therein.

\section{RESUME}

\section{L'Associativisme dans le Secteur de la Santé au Brésil et les Organisations Défendant les Intérêts des Patrons d'entreprises Médicales}

Cet article a pour but d'introduire une réflexion au sujet des possibilités de construction d'un pacte social ou de formes de concertation entre les 
acteurs organisés du secteur de la santé face aux impasses que rencontre l'implantation du Système Unique de Santé. Dans son exposition, l'auteur aborde des aspects théoriques où il analyse les relations entre l'Etat et la société civile sous l'angle du néo-corporatisme. Il aborde également la dimension associative de l'ordre social, l'échange politique entre les sphères publiques et privées ainsi que l'intermédiation d'intérêts organisés au sein de la policy-making des démocraties contemporaines. Il fait un examen du modèle d'organisation des intérêts, tel qu'il s'est structuré au long de l'histoire brésilienne tout en mettant en relief la forme hybride ou duale de la représentation. Prenant pour base un tableau synoptique qui illustre l'évolution de L'Associativisme sectoriel face aux politiques de santé, il examine des particularités telles que les formats de représentation (dual, trichotomyque) et la densité de la constellation d'associations représentatives des intérêts des professions, des producteurs de technologies de santé et, en particulier, des patrons d'entreprises médico-assistancielles. En définitive, face à la maturité et à la complexité de l'univers analysé, l'auteur s'interroge sur les conditions d'efficacité politique du Conseil de Santé, organisme créé pour réaliser des transformations structurelles et culturelles au sein du système de santé et locus propre à la concertation collective entre les groupes organisés de représentation d'intérêts. 


\section{Quadro Sinóptico \\ Organizações Nacionais de Interesse no Setor Saúde Brasileiro (1920-90)}
Decada Fatos Politico-institucıotiaıs maıs Relevantes Organizacōes do Enıpresariado Nivet Federal
Médico Assistencial Hospitalar
Caixas Aposentadorias e Pensōes - CAPs (1928)
30) Mınstérıo da Educaçào e Saude/Departamento Nacionaí da Saúde 11930 ,
Ministéro do Trabalho Indústrá e Coméreo (1930)/DNT
IAPs
41) Discussão Tramutacảo da Lei Orgânica dả Previdencia Social - LOPS no Congresso Nacional $+1947-60)$
MTIC/Departamento de Previdència Social (1948)

Programa ue Pronta Ação - PPA 11974

Lei Sistema Nacional de Saude (1975)

$8(0 / 90$ Planos de reformulaçáo:

Prograna Nacionai de Serviços Básicos de Saúde PREV-SAUDE (1980)

Programa de Ações lutegradas de Saúde - PAIS (1983)

Açōes Integradas de Saúde - AIS (1984)

VIII Conferência Nacional de Saúde (1986)

Sistema Unificado Descentralizado de Saúde SUDS (1987)

\section{CONSTITUIÇÃO 1988}

Leı Orgànıca da Saude (1990)

Federaçåo Nacional de Seguros Prıvados - Fenaseg (1951)

Associaçào Brasıleira de Hospitais - ABH 1954 )

Federação das Misericórdias (1958) (Santa Casa)

Federaçầ Brasileira cue Hospitais - FBH (1964)

Confederação das Misericórdias (1963) Associação

Brasileira de Medicina de Grupo - Abramge (1966)

Sıstema Unimed de Cooperativas Médicas (1967)

\section{Associação Nacional dos Médıcos}

que exercem em Grupo

Sociedade Brasileira de Medicina de Seguros

Associaçào Latino-Americana de Medicina Integral

- ALAMI (Sistenias Privados) (1980)

Associação Brasıleıra de Serviços Próprıos das

Empresas - Abraspe (1980)

Federação Nacional Je Estabelecimentos e Serviços de Saúde - Fenatess (1983)

Confederaçào das Unimeds (1983)

Sindicato Nacional de Medicina de Grupo - Sinamge Conselho Nacional de Medicina de Grupo - Conamge (1990)

Comitê de Integração de Entidades Fechadas de Assistência à Saúde - CIEFAS (1990)

Sistema Único de Saúde - SUDS* (Municipalizaçầo)

Ministério Saúde + INAMPs 
Organizaçòes do Empresariado

Industrial vinculado ao setor saúde
Organizações Profissionais e Representaçōes no Setor Público

Conselho Saúde Pública (1923)

Sindicato Médico Brasileiro (RJ) SINMED (1927)

Sindicato dos Enfermeiros Terrestres Associaçâo Nacional de Enfermeiras

Sindicato Odontológico do Brasil (RJ) (1931)

Conselho Nacional do Trabalho*

Conselho Nacional de Saúde* (1937)
Associação Brasileira da Indústria Farmacêutica Abifarma (1948)
Sindicato dos Farmacêuticos (SP) (1946)

Sindicato dos Enfermeiros e Empregados em Hospitais e Casas de Saúde (1945)

Conselho Federal de Medicına - CFM (Ordem dos Médicos) (1945)

Abifarma/Conselho Consultivo Técnico do Governo (1955)

Associação Brasileira da Indústria de Artigos e Equipamentos Médicos, Odontológicos e Hospitalares - Abimo (1964)
Conselho de Medicina da Previdência Social (1951)* Associação Médica Brasileira - AMB (1952) (Congrega e protocola sociedades de especialidades) Associação Brasileira de Enfermagem - Aben (1954)

Conselho Federal de Farmácia (1960) Sindicato dos Enfermeiros (diplomados) (1962)

Conselho Nacional de Seguros Privados - CNSP (1966)*

(Comissão Seguro Saúde)

Federação Nacional (Sindicatos) dos Médicos (1975)

Associação dos Psicólogos (1973)

Conselho Nacional de Saúde*

Conselho Federal de Enfermagem - Cofen (1975)

Associação dos Laboratórios Nacionais - Alanac (1985)
Conselho Consultivo de Administração de Saúde Previdenciária - Conasp (1981)*

Conselho de Saúde (Nacional, Estaduais e Municipais)* Conselho Nacional de Secretários Estaduais de Saúde Conass*

Conselho Nacional de Secretários Municipais de Saúde Conasem*

Sindicato dos Previdenciários - Sindiprev (1988/89
* Levantamento realizado por Maria Eliana Labra (ENSP/DAPS) 